Int. J. Electrochem. Sci., 12 (2017) 3283 - 3295

International Journal of

ELECTROCHEMICAL

SCIENCE

WWW.electrochemsci.org

\title{
Inhibition of C-steel Corrosion by Green Tea Extract in Hydrochloric Solution
}

R. Salghi ${ }^{1, *}$, S. Jodeh ${ }^{2}$, Eno E. Ebenso ${ }^{3, *}$, H. Lgaz ${ }^{1}$, D. Ben Hmamou ${ }^{1}$, M. Belkhaouda ${ }^{1}$, I. H. Ali ${ }^{4}$, M. Messali $^{5}$, B. Hammouti ${ }^{6}$, S. Fattouch ${ }^{7}$

${ }^{1}$ Laboratory of Applied Chemistry and Environment, ENSA, University Ibn Zohr, PO Box 1136.Agadir, Morocco.

${ }^{2}$ Department of chemistry, An_Najah National University, P.O. Box 7, Nablus, Palestine.

${ }^{3}$ Material Science Innovation \& Modelling (MaSIM) Research Focus Area, Faculty of Agriculture, Science and Technology, North-West University (Mafikeng Campus), Private Bag X2046, Mmabatho 2735, South Africa

${ }^{3}$ Department of chemistry, An-Najah National University, P.O. Box 7, Nablus, Palestine.

${ }^{4}$ Chemistry Department of, College of Science, King Khalid University, Abha, Saudi Arabia

${ }^{5}$ Chemistry Department, Faculty of Science, Taibah University, 30002, Al-Madinah Al-Mounawwara, Saudi Arabia

${ }^{6}$ LCAE-URAC 18, Faculty of Science, University of Mohammed Premier, Po Box 71760000 Oujda, Morocco

${ }^{7}$ LIP-MB, INSAT, University of Carthage, Tunisia.

*E-mail: r.salghi@uiz.ac.ma ; Eno.Ebenso@nwu.ac.za

doi: $10.20964 / 2017.04 .46$

Received: 13 August 2016 / Accepted: 22 February 2017 / Published: 12 March 2017

Inhibition ability of green tea extract (GTE) on the C38 steel (CS) in $1.0 \mathrm{M} \mathrm{HCl}$ was evaluated using different methods such as: weight loss, electrochemical impedance spectroscopy (EIS) and potentiodynamic polarization $(P D P)$ methods at various temperatures. Polarisation curves show that GTE acts essentially as mixed-type inhibitor controlling cathodic and anodic reactions with slight predominant in cathodic branches. EIS results indicate the increase of resistance transfer $\left(R_{\mathrm{t}}\right)$ while double layer capacitance $\left(\mathrm{C}_{\mathrm{dl}}\right)$ decrease in the rise of green tea extract (GTE) concentrations. Obtained results also showed that the inhibition efficiency decreased with a rise in the temperature. Activation energy $\left(E_{\mathrm{a}}\right)$, enthalpy $\left(\Delta H_{a}{ }^{*}\right)$ and entropy and $\left(\Delta S_{a}{ }^{*}\right)$ of corrosion process were estimated using experimental measurements.

Keywords: Inhibition, Corrosion, Green Tea Extract, Steel 


\section{$\underline{\text { FULL TEXT }}$}

(C) 2017 The Authors. Published by ESG (www.electrochemsci.org). This article is an open access article distributed under the terms and conditions of the Creative Commons Attribution license (http://creativecommons.org/licenses/by/4.0/). 